\title{
Evaluation of anticancer activity of water and juice extracts of young Hordeum vulgare in human cancer cell lines HT-29 and A549
}

\author{
Arkadiusz Czerwonka', Katarzyna Kawka ${ }^{1,2}$, Klaudia Cykier', Marta Kinga Lemieszek², \\ Wojciech Rzeski ${ }^{1,2}$
${ }^{1}$ Departament of Virology and Immunology, Institute of Biology and Biochemistry, Maria Curie-Skłodowska University ${ }^{2}$ Department of Medical Biology, Institute of Rural Health, Lublin, Poland

Czerwonka A, Kawka K, Cykier K, Lemieszek M. K, Rzeski W. Evaluation of anticancer activity of water and juice extracts of young Hordeum vulgare in human cancer cell lines HT-29 and A549. Ann Agric Environ Med. 2017; 24(2): 345-349. https://doi.org/10.26444/aaem/74714

\begin{abstract}
Introduction and objective. Barley (Hordeum vulgare L.) is known as a rich source of different bioactive compounds. At present, considerable attention of researchers is focused on young barley grass. It can be a good source of dietary minerals, vitamins, carbohydrates, amino acids, phenolic compounds and proteins. It is possible that the composition of chemical ingredients beneficial for health may induce an anticancer potential of young barley in human colon adenocarcinoma (HT29) and human lung adenocarcinoma (A549) cell lines.

Materials and method. Hordeum vulgare water extract (HWE) and Hordeum vulgare juice extract (HJE) were prepared. Cell proliferation and viability were examined with the use of MTT (3-(4,5-dimethylthiazol-2-yl)-2,5-diphenyltetrazolium bromide) and NR (neutral red) methods. Induction of necrosis was assessed by propidium iodide/Hoechst staining. Progress of the cell cycle involved in cell proliferation, apoptosis, and regulation of transcription was estimated using flow cytometry analysis. Additionally, the capability of free radical scavenging was evaluated with the DPPH assay.

Results. The study revealed that extracts inhibited the proliferation of cancer cells. The NR study confirmed the low cytotoxic activity of the tested extracts to normal human colon epithelial cells (CCD 841 CoTr) and human skin fibroblasts (HSF). Furthermore, a dose-dependent cytotoxicity against HT-29 cells, but not A549 cells, has been reported. The free radical scavenging activity was observed in the case of the HWE but not the HJE.

Conclusions. The obtained results indicate a cancer chemopreventive potential of young barley as a safe dietary agent in colon carcinoma.
\end{abstract}

\section{Key words}

Hordeum vulgare, colon cancer, lung cancer, inhibition of proliferation, necrosis

\section{INTRODUCTION}

Barley (Hordeum vulgare L.) is one of the most commonly cultivated cereals worldwide (ca. 30\% of the world grain production). Most barley crops are produced in Europe, Asia, and North Africa. Barley is widely used as a dietary supplement, a raw material in baking and brewing, animal fodder, as well as a drug in traditional folk medicine (Japanese barley tea) $[1,2]$.

Barley grains contain a high concentration of carbohydrates, such as starch (65-68\%) and dietary fibre (11-34\%), proteins (10-17\%), $\beta$-glucans, (4-9\%, generally $\beta$ - $(1,3 / 1,4)$-glucan), some free lipids (2-3\%), minerals (1.5-2.5\%), and vitamins [1]. However, it has been shown that grass extracts usually contain a higher concentration of proteins (45.2\%) than carbohydrates (23.2\%) and lipids (3.2\%) [3]. Moreover, young barley grass can be a good source of dietary minerals (especially sodium, magnesium, iron, copper, and phosphorous) and vitamins (thiamine, riboflavin, tocopherols and tocotrienols, biotin, folic acid, and pantothenic acid), which are richer than those found in some popular vegetables (spinach, tomato, lettuce), fruits (banana), dairy products (cow's milk), and fish (canned

Address for correspondence: Arkadiusz Czerwonka, Departament of Virology and Immunology, Institute of Biology and Biochemistry, Maria Curie-Skłodowska University

E-mail: arkadiusz.czerwonka@poczta.umcs.lublin.pl

Received: 23 March 2017; accepted: 9 May 2017; first published on June 2017 salmon) [3]. Furthermore, young barley grass has a high content of glucose (15.4-88.4 g/kg dry weight), fructose (37.6-81.4 g/kg dry weight), aspartic acid (15.23-28.68 g/kg dry weight), glutamic acid (16.69-35.52 g/kg dry weight), and ascorbic acid [4]. Interestingly, many different phenolic compounds including flavones (e.g. major leaf antioxidants, such as saponarin, lutonarin, and 2-O-glucosylvitexin), leucoanthocyanidins, catechins, and coumarins have been found in young barley extracts. The total level of polyphenolic compounds in barley grass varies from $857-1,690 \mathrm{mg} / \mathrm{kg}$ dry mass [5] and one of them - 5,7-dihydroxyflavone - tricin, has been characterized as a melanin biosynthesis inhibitor [6].

Besides phenolic compounds, some chemopreventive barley proteins have been described in literature. Lunasin, a 43-amino-acid peptide isolated from barley, inhibited tumorigenesis in ras-transfected mouse fibroblasts treated with isopropyl- $\beta$-d-thiogalactoside (IPTG) [7].

Clinical studies have shown that young barley-containing products may lower blood pressure and reduce the risk of coronary heart disease [8], decrease the serum cholesterol level [9], lower the risk of Type 2 diabetes, reduce symptoms of rheumatoid arthritis, accelerate body tissue repair, and help to prevent gallstone formation [2]. Furthermore, there is ample evidence that young barley possesses immunostimulatory [10], anticancer [11, 12], antidepressant-like [13], prebiotic [14], and antiulcer properties [15]. In other studies, it has been revealed that, barley consumption may improve human 
organism disorders like improper body weight, liver injury, allergy, body odour, wrinkles, and tired skin [3].

Despite the development of medicine, one in four deaths in industrialized countries is due to cancer. Lung cancer is the most commonly diagnosed cancer disease and the main cause of death globally. The major factors associated with development of lung cancer include tobacco smoking, heavy air pollution, and exposition to carcinogens such as asbestos, arsenic, radon, or polycyclic aromatic hydrocarbons [16, 17]. In turn, the third most commonly diagnosed and the second in terms of worldwide mortality is colorectal cancer (CRC) [18]. There are several factors associated with the development of CRC, e.g. diet high in animal fat and red meat, together with low intake of fruits and vegetables, environmental risk factors, low physical activity, obesity, and heavy alcohol consumption $[19,20,21]$.

\section{OBJECTIVES}

Based on the broad spectrum of beneficial compounds present in young barley, the aim of the present study was an in vitro evaluation of the anticancer potential of its extracts in a colon and lung carcinoma cell culture model.

\section{MATERIALS AND METHOD}

Barley extracts. Young barley powder (milled dried grass, INTENSON, Całowanie 94G05-480 Karczew) and juice (EkaMedica, Bielska 78a, 43-340 Kozy) were purchased in a local market. Five grams of milled dried powder were suspended in $200 \mathrm{ml}$ of pure sterile water and extracted on a magnetic stirrer for $24 \mathrm{~h}$ at room temperature. The solution was then centrifuged (10 min, 5,000 rpm, [2,655×g]), filtered, and vacuum evaporated (vacuum rotary evaporator type 350 , UNIPAN, Warsaw, Poland). The second extract was a barley juice extract (HJE). Barley juice $(200 \mathrm{ml})$ was filtered and vaporized in a rotary vacuum. Stock solutions $(100 \mathrm{mg} / \mathrm{ml})$ were prepared in Dulbecco's Modified Eagle's Medium low glucose (D6046)/Dulbecco's Modified Eagle's Medium/ Nutrient Mixture F-12 (D8437) (1:1) (A549, HSF) or D8437 (HT-29, CCD 841 CoTr) culture medium (Sigma Chemicals, St. Louis, MO, USA).

Cell Cultures. Human colon adenocarcinoma cell line HT-29, human colon epithelial cell line CCD 841 CoTr, and human lung adenocarcinoma cell line A549 were obtained from the American Type Culture Collection (ATCC, Menassas, VA, USA). Human skin fibroblasts (HSF) were obtained with the outgrowth technique from skin explants from young volunteers. The cells were cultured in DMEM F12 Ham (HT-29, CCD 841 CoTr) or DMEM - low glucose/DMEM F12 Ham (1:1) (A549, HSF) containing 10\% fetal bovine serum (FBS - Sigma), 100 units/ml penicillin (Sigma), and $100 \mu \mathrm{g} / \mathrm{ml}$ streptomycin (Sigma) at $37^{\circ} \mathrm{C}$ (HT-29, A549, HSF) or $33^{\circ} \mathrm{C}$ (CCD $841 \mathrm{CoTr}$ ) in a humidified atmosphere of $95 \%$ air and $5 \% \mathrm{CO}_{2}$.

Cell proliferation - MTT assay. The metabolic activity of growing cells was assessed by means of the MTT assay. In the test, yellow tetrazolium salt MTT (3-(4,5-dimethylthiazol-2yl)-2,5-diphenyltetrazolium bromide - Sigma) is metabolized by viable cells to purple formazan crystals. HT-29 and A549 cells were plated on flat-bottom 96-well microplates at a density of $3 \times 10^{4}$ cells $/ \mathrm{ml}$ (HT-29) and $1 \times 10^{4}$ (A549) cells $/ \mathrm{ml}$ in $100 \mu \mathrm{l}$ of a complete growth medium. The next day, the culture medium was removed and the cells exposed to serial dilutions of $\mathrm{HWE}$ and $\mathrm{HJE}$ at concentrations ranging from $0.1-5 \mathrm{mg} / \mathrm{ml}$. After 96-hour incubation, the cells were incubated for $3 \mathrm{~h}$ with an MTT solution $(5 \mathrm{mg} / \mathrm{ml})$, and formazan crystals then solubilized overnight by adding SDS buffer $(10 \%$ SDS in $0.01 \mathrm{~N} \mathrm{HCl})$. The colour product of the reaction was quantified by measuring absorbance at a $570 \mathrm{~nm}$ wavelength using an Emax Miocroplate Reader (Menlo Park, CA, USA). $\mathrm{IC}_{50}$ was calculated using the computerized linear regression analysis of quantal log dose-probit functions, according to the method of Litchfield and Wilcoxon. Cell proliferation (\%) was expressed as a percentage relative to the untreated control cells [22].

Cell viability - Neutral Red (NR) assay. The neutral red assay determines the accumulation of neutral red dye in the lysosomes of viable, uninjured cells. The HT-29, CCD 841 CoTr, A549, and HSF cells were plated on 96-well microplates at a density of $1 \times 10^{5}$ cells $/ \mathrm{ml}$ in a complete growth medium. After 24-hour incubation, the growth medium was replaced by a fresh medium (containing $2 \%$ FBS) and the cells exposed to serial dilutions of HWE and HJE $(0.1-5 \mathrm{mg} / \mathrm{ml})$. After $24 \mathrm{~h}$, the cells were incubated with the NR reagent for $3 \mathrm{~h}$, fixed with the $\mathrm{NR}$ fixative solution ( $1 \% \mathrm{CaCl}_{2}$ in $0.5 \%$ formalin) for $3 \mathrm{~min}$ at room temperature, and solubilized in $1 \%$ acetic acid in $50 \%$ ethanol under shaking for $20 \mathrm{~min}$. Absorbance was measured at $550 \mathrm{~nm}$ using an Emax Miocroplate Reader [23].

Necrosis and apoptosis detection - Propidium iodide and Hoechst 33342 solution staining. The staining mixture of propidium iodide (PI) (Sigma) stains cells with damaged cytoplasmic membrane (necrosis) in red. Hoechst 33342 (Sigma) stains uninjured non-apoptotic cells in blue and condensed chromatin of apoptotic cells in bright blue. The HT-29 and A549 cells were plated on cell culture Petri dishes (Nunc) at a density of $5 \times 10^{4}$ cells $/ \mathrm{ml}$. The next day, the cells were exposed to $0.25 ; 0.5$; and $0.75 \mathrm{mg} / \mathrm{ml}$ of $\mathrm{HWE}$ for $24 \mathrm{~h}$ and $48 \mathrm{~h}\left(37^{\circ} \mathrm{C} ; 5 \% \mathrm{CO}_{2}\right)$. Next, the medium was removed and the cells washed with $0.5 \mathrm{ml}$ of pre-warmed PBS, followed by incubation with the staining solution [propidium iodide $(0.15 \mathrm{mg} / \mathrm{ml})$, and Hoechst $33342(0.24 \mathrm{mg} / \mathrm{ml})$ in a serumfree culture medium] in darkness for $5 \mathrm{~min}$. The percentage of apoptotic and necrotic cells was assessed with Confocal Microscopy using a Nikon Eclipse Ti microscope and the NIS-Elements (Nikon) and ImageJ software (developed by Wayne Rasband) [24].

Cell cycle progression - Propidium iodide staining. Propidium iodide (PI) staining is a method for analysis of cellular DNA content by flow cytometry. The HT-29 and A549 cells were seeded on 6-well microplates at a density of $5 \times 10^{5}$ cells $/ \mathrm{ml}$. After 24 -h incubation, the cells were exposed to $0.5 ; 1 ; 2.5 ; 5$; and $7.5 \mathrm{mg} / \mathrm{ml}$ of the HWE for the next $24 \mathrm{~h}$ (at $37^{\circ} \mathrm{C}$ and $5 \% \mathrm{CO}_{2}$ ). Next, the medium was removed and, the cells washed with PBS and collected in a $5 \mathrm{mM}$ EDTA/PBS solution. After centrifugation (10 min; $1,500 \mathrm{rpm}[239 \times \mathrm{g}])$, the cells were fixed with $70 \%$ ice-cold ethanol and then stored at $-20^{\circ} \mathrm{C}$. PI/RNase (BD) staining was performed directly before flow cytometric (BD FACSCalibur) 
analysis. The PI fluorescence intensity of individual nuclei was determined and at least 10,000 events were measured within an acquisition rate $>60$ events/sec. Cell cycle analyses were performed with the use of software CellQuest Pro Version 6.0. for Macintosh operating system [25].

Free radical scavenging activity - DPPH assay. The free radical scavenging activity of HWE and HJE was measured with the 1,1-diphenyl-2-picrylhydrazyl (DPPH) assay. This method is based on the ability of antioxidants to reduce the stable dark violet radical DPPH (Sigma) to the yellow colored diphenyl-picrylhydrazine. Briefly, $100 \mu$ l of the DPPH solution $(0.2 \mathrm{mg} / \mathrm{ml}$ in ethanol) were added to standards and to 100 $\mu \mathrm{l}$ of $0.1 ; 0.25 ; 0.5 ; 0.75 ; 1 ; 2.5$; and $5 \mathrm{mg} / \mathrm{ml} \mathrm{HWE}$ and HJE. Trolox (6-hydroxy-2,5,7,8-tetramethylchroman-2-carboxylic acid - Sigma) at increasing concentrations $(1-50 \mu \mathrm{g} / \mathrm{ml})$ was used as a standard for free radical scavenging activity. After 20 min. incubation at room temperature, the absorbance of the solution was measured at $515 \mathrm{~nm}$. The lower the absorbance, the higher the free radical scavenging activity of the extracts. The activity of each extract was determined by comparing its absorbance with that of a control solution (reagents without extract) and standards. The capability to scavenge DPPH radical was calculated by the following formula: DPPH scavenging effect $(\%)=[(\mathrm{Xcontrol}-\mathrm{Xextract} / \mathrm{Xcontrol}) \times$ $100]$ where Xcontrol is the absorbance of the control and Xextract is the absorbance in the presence of extracts [23].

Statistical analysis. The data were expressed as means \pm standard deviation. Statistical analyses were performed using GraphPad Prism 5.0 (GraphPad Software Inc., CA, USA). The data were analyzed by one-way ANOVA test, Tukey's Multiple Comparison Post-test; ${ }^{*} \mathrm{p}$ values $<0.05,{ }^{* *} \mathrm{p}$ values $<0.01,{ }^{* *} \mathrm{p}$ values $<0.001$, were considered to be significant.

\section{RESULTS AND DISCUSSION}

The results are presented in Figures S1 - S4 and Table ST1.

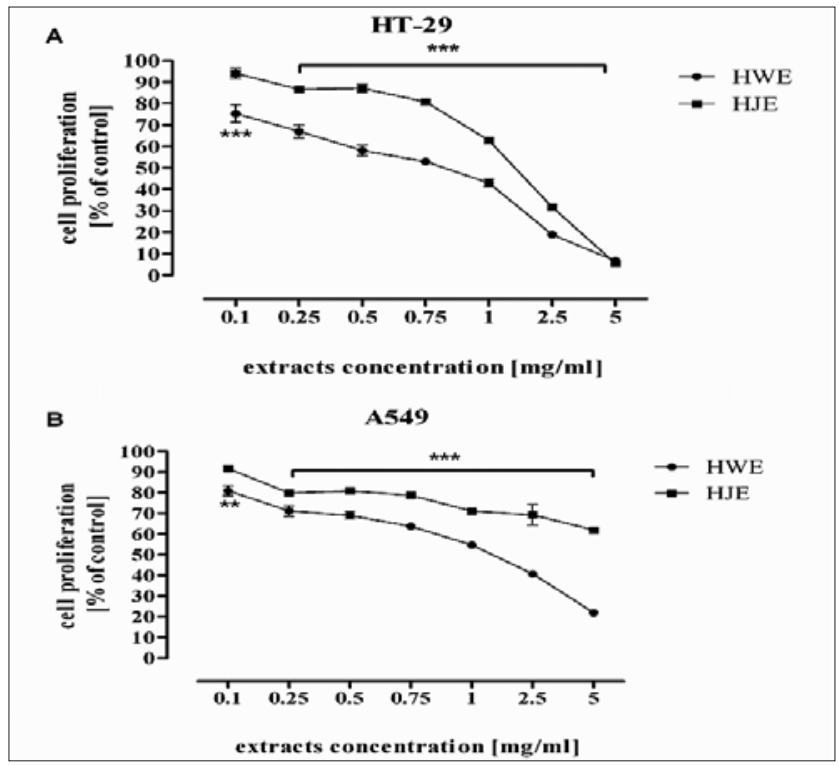

Figure S1. Influence of HWE and HJE on the proliferation of (A) HT-29 human colon adenocarcinoma, and (B) A549 human lung adenocarcinoma cell lines treated with the extracts at various concentrations for $96 \mathrm{~h}$ where ${ }^{* *}$ indicates $p<0.01$ and ${ }^{* * *} p<0.001$
The presented study shows the anticancer potential of the young barley in both HT-29 (human colon adenocarcinoma) and A549 (human lung adenocarcinoma) cancer cells. In the first step, the antiproliferative effect of HWE and HJE was determined using an MTT [3-(4,5-dimethylthiazol-2-yl)-2,5diphenyltetrazolium bromide] assay. Both extracts exerted a dose-dependent antiproliferative effect in the HT-29 cells. After $96 \mathrm{~h}$ exposure, the highest concentration $5 \mathrm{mg} / \mathrm{ml}$ $\mathrm{HWE}$ and HJE decreased cell proliferation to $6.7 \%$ and $5.5 \%$ vs. control cells (Fig. S1A). The $\mathrm{IC}_{50}$ value [concentration causing proliferation inhibition by $50 \%$ ] compared to control was calculated according to the Litchfield and Wilcoxon method [26]; HWE and HJE were calculated at $0.7 \mathrm{mg} / \mathrm{ml}$ and $2.4 \mathrm{mg} / \mathrm{ml}$, respectively. In the case of the A549 cells, the highest HWE and HJE concentrations also reduced cell proliferation to $22 \%$ and $62 \%$, respectively (Fig. S1B); however, the $\mathrm{IC}_{50}$ value of both extracts was higher $(1.3 \mathrm{mg} / \mathrm{ml}$ and $7.4 \mathrm{mg} / \mathrm{ml}$, respectively) compared to that for the HT-29 cells.

Recently, the antiproliferative potential of young barley extracts has been revealed in breast cancer cells [27]. In the study by Kubatka et al., the tested barley extract at the concentration $1 \mathrm{mg} / \mathrm{ml}$ decreased MCF-7 breast cancer cells proliferation to $37.93 \%$ after $72 \mathrm{~h}$ treatment.

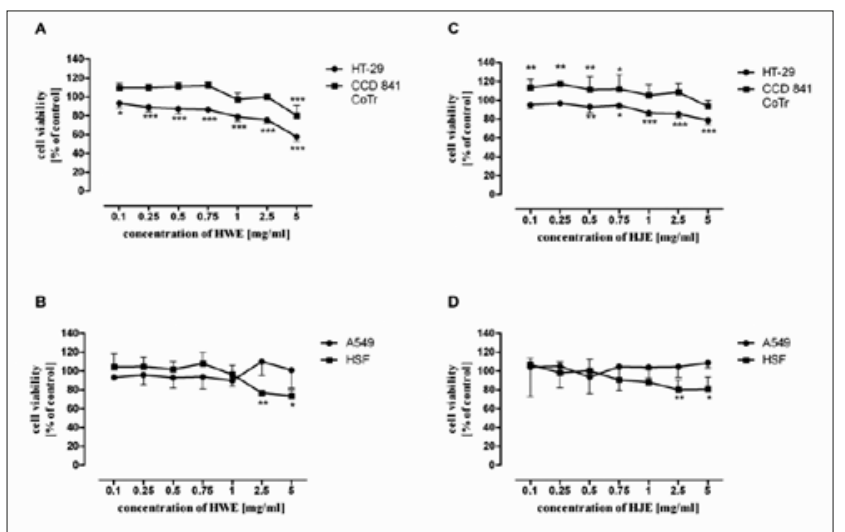

Figure S2. Influence of HWE and HJE on cell viability of (A, C) HT-29 human colon adenocarcinoma, and CCD 841 CoTr human colon epithelial, and (B, D) A549 human lung adenocarcinoma, and HSF human skin fibroblasts cell lines treated with the extracts at various concentrations for $24 \mathrm{~h}$ where * indicates $p<0.05$, ** $\mathrm{p}<0.01$ and ${ }^{* * *} \mathrm{p}<0.001$

In order to verify the cytotoxicity of the extracts against normal and cancer cells, the NR (neutral red) cell viability assay was applied. The experiments showed that the colon carcinoma cells were more sensitive to the tested extracts (the $\mathrm{IC}_{50}$ value of HWE and HJE was calculated at $9.3 \mathrm{mg} / \mathrm{ml}$ and $48.1 \mathrm{mg} / \mathrm{ml}$, respectively) than the normal colon epithelial cells. The viability of the cancer cells was decreased in a dose-dependent fashion, whereas normal CCD841 CoTr cells were unaffected in the entire concentration range $(\mathrm{HJE})$ and up to $2.5 \mathrm{mg} / \mathrm{ml}$ (HWE) (Fig. S2A, S2C). Moreover, a significant increase in neutral red uptake was observed in normal cells, compared to the control cultures, which suggests protective or trophic properties. This phenomenon requires further studies in order to prove the beneficial effects of young barley in normal colon epithelium. Animal studies [28] have shown that young barley leaf powder shortened gastrointestinal transit time and decreased $\mathrm{pH}$ of the gut. This may lead to a decreased colorectal cancer risk by reduced carcinogen exposition time in the gut and suppression of 
local inflammation. It should also be noted that similar results were obtained [29] showing cytotoxicity of a barley water extract against human cervical JTC-26 cancer cells, but not against human normal embryonic cells (HE-1 line). In contrast, lung carcinoma A549 cells were not sensitive to both extracts in the entire concentration range tested. Moreover, a significant cytotoxic effect at a higher extract concentrations was observed in cultures of normal skin fibroblasts (Fig. S2B, S2D). This may suggest tissue specificity of the tested young barley extracts.

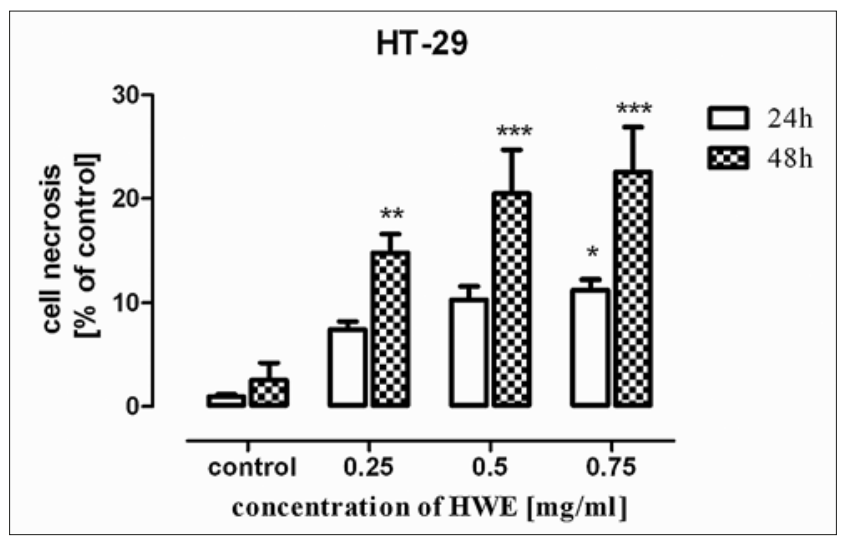

Figure S3. Influence of HWE on the necrosis of HT-29 human colon adenocarcinoma cell line treated with the extract at various concentrations for 24 and $48 \mathrm{~h}$ where ${ }^{*}$ indicates $p<0.05,{ }^{* *} p<0.01$ and ${ }^{* * *} p<0.001$

Because the HWE extract showed stronger anticancer activity, it was selected for further studies. To verify whether HWE induced necrotic or apoptotic cell death, differential staining of propidium iodide and Hoechst was applied. In the HT-29 cell culture, it was shown that $24 \mathrm{~h}$ exposure at concentrations $0.25,0.5$, and $0.75 \mathrm{mg} / \mathrm{ml}$ induced necrosis in $7.4 \%, 10.2 \%$, and $11.2 \%$ cells, respectively. Furthermore, after $48 \mathrm{~h}$, the level of necrotic cells increased to $14.7 \%, 20.4 \%$, and $22.5 \%$, respectively (Fig. S3). In the presented study, HWE did not induce apoptosis in the HT-29 cells. Further experiments showed that, in the case of the A549 lung carcinoma cells, the tested extract did not evoke any changes (data not shown). The results obtained confirm the specificity of the HWE extract against colon carcinoma cells.

The antioxidant activity is a very important feature of potential chemopreventive agents. Recently, the presence of

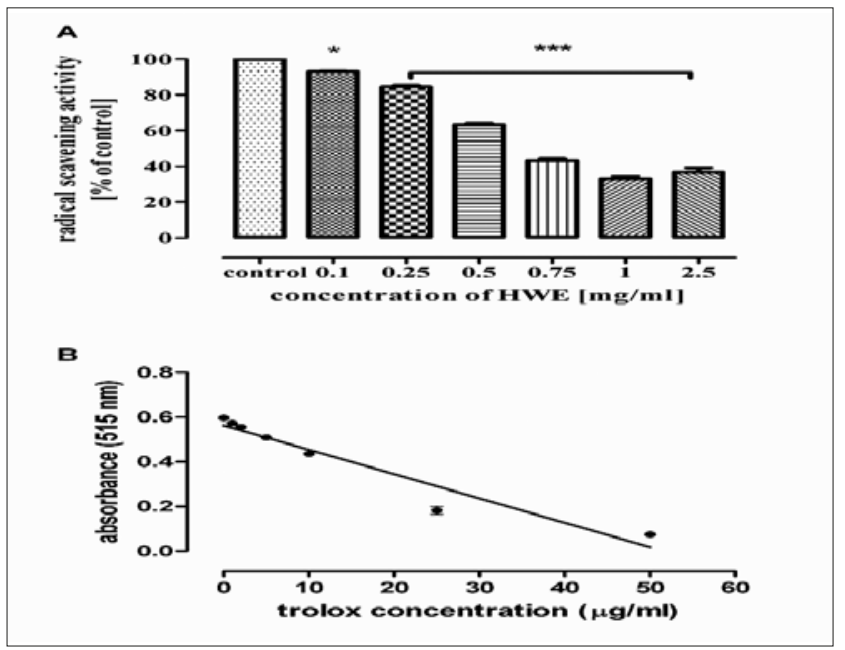

Figure S4. Influence of HWE on free radical scavenging activity (A) compared to Trolox where ${ }^{*}$ indicates $p<0.05$, and ${ }^{* *} p<0.001$, and (B) standard line graph of Trolox in DPPH activity

a potent antioxidant flavonoid - saponarin - in young barley extracts has been described [30]. In the current study, the HWE extract within the concentration range of $0.1-1 \mathrm{mg} / \mathrm{ml}$ showed a dose-dependent antioxidative activity in the DPPH (2,2-diphenyl-1-picrylhydrazyl) scavenging assay. The highest scavenging action was observed at $1 \mathrm{mg} / \mathrm{ml}$, which is an equivalent of $33.6 \mu \mathrm{g} / \mathrm{ml}$ of Trolox activity (Fig. S4). In contrast, no such activity was found in the case of the HJE extract (data not shown).

The inhibition of cancer cell cycle progression is very often described as one of the mechanisms of anticancer action. Such an activity of young barley was described by Kubatka in MCF-7 breast cancer cells [27]. In the presented study, no significant changes were observed in the HT-29 and A549 cells cell cycle progression after exposure to the HWE extract (Tab. ST1A, ST1B).

\section{CONCLUSIONS}

Initial studies revealed an anticancer potential of young barley in colon carcinoma cells. The observed effects were attributed to cancer cell proliferation inhibition, necrosis induction, and noticeable antioxidant activity. Of note is

Table ST1. Influence of HWE on percentage of cell population in each phase of the cell cycle of (A) HT-29 human colon adenocarcinoma, and (B) A549 human lung adenocarcinoma cell lines treated with the extract at various concentrations for 24 h. $G_{1}-G_{1}$ cell cycle phase, $S-S$ cell cycle phase, and $G_{2}-G_{2}$ cell cycle phase

HT-29

\begin{tabular}{lcccccc} 
cell cycle phases & Control & $0.5 \mathrm{mg} / \mathrm{ml}$ & $1 \mathrm{mg} / \mathrm{ml}$ & $2.5 \mathrm{mg} / \mathrm{ml}$ & $5 \mathrm{mg} / \mathrm{ml}$ & $71.85 \pm 0.86$ \\
\hline $\mathrm{G}_{1}$ & $72.76 \pm 0.65$ & $71.91 \pm 1.09$ & $69.58 \pm 1.41$ & $72.04 \pm 0.47$ & $67.21 \pm 1.7$ & $7.52 \pm 0.18$ \\
\hline $\mathrm{S}$ & $6.42 \pm 0.41$ & $7.6 \pm 0.72$ & $7.21 \pm 1.59$ & $6.73 \pm 0.21$ & $7.03 \pm 0.38$ \\
\hline $\mathrm{G}_{2}-\mathrm{M}$ & $18.36 \pm 0.69$ & $19.03 \pm 0.53$ & $19.94 \pm 1.62$ & $19.13 \pm 0.07$ & $18.01 \pm 0.95$ & $19.57 \pm 1.67$ \\
\hline
\end{tabular}

B

A549

\begin{tabular}{|c|c|c|c|c|c|c|}
\hline cell cycle phases & Control & $0.5 \mathrm{mg} / \mathrm{ml}$ & $1 \mathrm{mg} / \mathrm{ml}$ & $2.5 \mathrm{mg} / \mathrm{ml}$ & $5 \mathrm{mg} / \mathrm{ml}$ & $7.5 \mathrm{mg} / \mathrm{ml}$ \\
\hline $\mathrm{G}_{1}$ & $63.45 \pm 1.07$ & $62.37 \pm 1.43$ & $62.51 \pm 1.59$ & $62.37 \pm 0.62$ & $64.44 \pm 0.48$ & $64.01 \pm 0.68$ \\
\hline S & $7.69 \pm 0.09$ & $6.88 \pm 1.01$ & $6.64 \pm 0.86$ & $8.11 \pm 0.37$ & $5.73 \pm 0.28$ & $5.33 \pm 0.47$ \\
\hline
\end{tabular}


the fact that the tested young barley extracts were not toxic to normal colon epithelial cells. These findings support the opinion that young barley could be applied as a safe dietary chemopreventive agent.

\section{REFERENCES}

1. Baik BK, Ullrich SE. Barley for food: Characteristics, improvement, and renewed interest. J Cereal Sci. 2008; 48(2): 233-242.

2. Prasad R, Prasad LC, Bornare SS. Barley (Hordeum vulgare L.) crops (Model species), its use as food, feed, medicines and performed better when climatic conditions are unfavorable. Indian Journal of Crop Ecology 2014; 2(2): 47-52.

3. Hagiwara Y, Cichoke AJ. Barley leaves extract for everlasting health. Green Foods Corp. and Japan Pharmaceutical Development. 1998: 7(10): 15 .

4. Paulickova I, Ehrenbergerová J, Fiedlerova V, Gabrovská D, Havlová P, Holasová M, et al. Evaluation of barley grass as a potential source of some nutritional substances. Czech J Food Sci. 2007; 25(2): 65-72.

5. Dudjak JJ, Lachman D, Miholová D, Kolihová V, Pivec. Effect of cadmium on polyphenol content in young barley plants (Hordeum vulgare L.). Plant Soil Environ. 2004; 11(11): 471-477.

6. Meng TX, Irino N, Kondo R. Melanin biosynthesis inhibitory activity of a compound isolated from young green barley (Hordeum vulgare L.) in B16 melanoma cells. J Nat Med. 2015; 69(3): 427-431.

7. Jeong HJ, Lam Y, Lumen BO. Barley Lunasin supresses ras-induced colony formation and inhibits core histone acetylation in mammalian cells. J Agric Food Chem. 2002; 50: 5903-5908.

8. Izydorczyk MS, Dexter JE. Barley $\beta$-glucans and arabinoxylans: Molecular structure, physicochemical properties, and uses in food products-a Review. Food Res Int. 2008; 41(9): 850-868.

9. Pins JJ, Kaur H. A review of the effects of barley $\beta$-glucan on cardiovascular and diabetic risk. Cereal Foods World. 2006; 51(1): 8-11.

10. Kim H, Kwak BS, Hong HD, Suh HJ, Shin KS. Structural features of immunostimulatory polysaccharide purified from pectinase hydrolysate of barley leaf. Int J Biol Macromol. 2016; 87: 308-316.

11. Oliveira RJ, Ribeiro LR, da Silva AF, Matuo R, Mantovani MS Evaluation of antimutagenic activity and mechanisms of action of betaglucan from barley, in CHO-kl and HTC cell lines usin micronucleus test. Toxicol In Vitro. 2006; 20: 1225-1233.

12. Robles-Escajeda E, Lerma D, Nyakeriga AM, Ross JA, Kirken RA, Aguilera RJ, et al. Searching in mother nature for anti-cancer activity: antiproliferate and pro-apoptic effect elicited by green barley on leukemia/lymphoma cells. PLoS ONE. 2013; 8(9): 1-16.

13. Yamaura K, Nakayama N, Shimada M, Bi Y, Fukata H, Ueno K. Antidepressant-like effects of young green barley leaf (Hordeum vulgare L.) in the mouse forced swimming test. Pharmacognosy Res. 2012; 4: $22-26$.

14. Kanauchi O, Mitsuyama K, Andoh A, Iwanaga T. Modulation of intestinal environment by prebiotic germinated barley foodstuff prevents chemo-induced colonic carcinogenesis in rats. Oncol Rep. 2008; 20: 793-801.

15. Ohtake H, Yuasa H, Komura C, Miyauchi T, Hagiwara Y, Kubota K. Studies on the constituents of green juice from young barley leaves. Antiulcer activity of fraction from barley juice. Yakugaku Zasshi. 1985; 105: 1045-1051.

16. Jemal A, Bray F, Center MM, Ferlay J, Ward E, Forman D. Global cancer statistics. CA Cancer J Clin. 2011; 61(2): 69-90.

17. Ferlay J, Soerjomataram I, Dikshit R, Eser S, Mathers C, Rebelo M, et al. Cancer incidence and mortality worldwide: Sources, methods and major patterns in GLOBOCAN 2012. Int J Cancer. 2015; 136(5): 359-386.

18. Siegel R, Naishadham D, Jemal A. Cancer statistics, 2012. CA Cancer J Clin. 2012; 62(1): 10-29.

19. Mihajlovic-Bozic V. Risk factors for colorectal cancer. Arch Oncol. 2004; 12(1): 45-49.

20. Haggar FA, Boushey R.P. Colorectal cancer epidemiology: Incidence, mortality, survival, and risk factors. Clin Colon Rectal Surg. 2009; 22(4): 191-197.

21. Brevik A, Joshi AD, Corral R, Onland-Moret NC, Siegmund KD, Le Marchand L, et al. Polymorphisms in base excision repair genes as colorectal cancer risk factors and modifiers of the effect of diets high in red meat. Cancer Epidemiol Biomarkers Prev. 2010; 19(12): 3167-3173.

22. Matysiak J, Juszczak M, Karpińska MM, Langner E, Walczak K, Lemieszek MK, et al. Synthesis of 2-(2,4-dihydroxyphenyl)thieno1,3-thiazin-4-ones, their lipophilicity and anticancer activity in vitro. Mol Divers. 2015; 19(4): 725-36.

23. Paduch R, Trytek M, Król SK, Kud J, Frant M, Kandefer-Szerszeń $\mathrm{M}$, et al. Biological activity of terpene compounds produced by biotechnological methods. J Pharmaceutical Biology 2016; 54(6): 1096-1107.

24. Jakubowicz-Gil J, Langner E, Bądziul D, Wertel I, Rzeski W. Quercetin and sorafenib as a novel and effective couple in programmed cell death induction in human gliomas. Neurotox Res. 2014. 26(1): 64-77.

25. Sławińska-Brych A, Król SK, Dmoszyńska-Graniczka M, Zdzisińska B, Stepulak A, Gagoś M. Xanthohumol inhibits cell cycle progression and proliferation of larynx cancer cells in vitro. Chem. Biol. Interact. 2015; 240: 110-118.

26. Litchfield JT, Wilcoxon FA. A simplified method of evaluating doseeffect experiments. J Pharmacol Exp Ther. 1949; 96: 99-113.

27. Kubatka P, Kello M, Kajo K, Kruzliak P, Výbohová D, Šmejkal K, et al. Young barley indicates antitumor effects in experimental breast cancer in vivo and in vitro. Nutr Cancer. 2016; 68(4): 611-621.

28. Ikeguchi M, Tsubata M, Takano A, Kamiya T, Takagaki K, Ito H, et al. Effects of young barley leaf powder on gastrointestinal functions in rats and its efficacy-related physicochemical properties. Evid Based Complement Alternat Med. 2014; 2014: 7.

29. Sato A. Studies on anti-tumor activity of crude drugs. 1. The effects of aqueous extracts of some crude drugs in short-term screening test. Yakugaku Zasshi. 1989; 109(6): 407-423.

30. Kamiyama M, Shibamoto T. Flavonoids with potent antioxidant activity found in young green barley leaves. J Agric Food Chem. 2012; 60(25): $6260-6267$. 